\title{
Preventing Rsi/Wruld: use of esthesiometry to assess hand tactile sensitivity of slaughter- house workers
}

\author{
Reis, P. ${ }^{\mathrm{a}, \mathrm{b}, \mathrm{c}^{*}}$, Moro, A. ${ }^{\mathrm{a}, \mathrm{b}, \mathrm{d}}$ \\ a Programa de Pós-Graduação em Engenharia de Produção, Universidade Federal de Santa Catarina, SC, Brazil \\ ${ }^{\mathrm{b}}$ Universidade Federal de Santa Catarina, SC, Brasil \\ 'Instituto de Ensino Superior de Foz do Iguaçu, Pr, Brazil \\ ${ }^{\mathrm{d}}$ Programa de Pós-Graduação em Educação Física, Universidade Federal de Santa Catarina, SC, Brazil
}

\begin{abstract}
This research was conducted with slaughterhouse female workers in the municipality of São Miguel do Iguaçu, state of Parana, Brazil. The sample was composed of 103 women aged 25 to $40 \pm 7.57$ years, and the study aimed to verify the nerve conduction of the median nerve. An esthesiometer consisting of a Semmes-Weinstein monofilaments was used to measure the hand skin sensitivity in the region of the median nerve and a Jamar ${ }^{\circledR}$ hand dynamometer, which was used to determine the handgrip strength. About $81 \%$ of individuals had normal sensitivity with $0.05 \mathrm{~g}$ and average levels of handgrip strength in dominant hand (DH) of $35.30 \mathrm{kgf}( \pm 3.10)$ and in the non-dominant hand $(\mathrm{NDH})$ of $28.30 \pm 3.09 \mathrm{kgf} .14 \%$ of individuals had reduced sensitivity, with values equivalent to $0.2 \mathrm{~g}$ and $2.0 \mathrm{~g}$ (blue and violet) and levels of handgrip strength in the DH equal to $28.10 \mathrm{kgf}( \pm 2.90)$ and in the $\mathrm{NDH}$ of $26.40 \mathrm{kgf}( \pm 3.28) .5 \%$ of individuals showed bilateral sensitivity deficit $(4.0 \mathrm{~g})$ and levels of handgrip strength in the DH of $16.10 \mathrm{kgf}( \pm 2.10)$ and in the NDH of $18.20 \mathrm{kgf}( \pm 3.28)$, resulting in a strong correlation between handgrip strength and sensitivity of the median nerve $(\mathrm{r}=0.786)$ between variables dominant hand $(\mathrm{DH})$ and $(\mathrm{r}=0.626)$ for the non-dominant hand $(\mathrm{NDH})$. It could be concluded that assessing the nerve conduction of the median nerve by hand esthesiometry can be an important tool in preventing the Carpal Tunnel Syndrome.
\end{abstract}

Keywords: Carpal Tunnel Syndrome, handgrip strength, nerve conduction

\section{Introduction}

In contemporary Brazil, the meat processing industry has increased significantly, which represents an important landmark in the country's economy. Increasing export levels are clear evidence of this fact, resulting in a great generation of jobs in this sector [2]. However, the intense pace of work and lack of breaks to recover from fatigue in slaughterhouses in Brazil is the leading cause of Repetitive Strain Injuries (RSI) and Work-Related Upper Limb Disorders (WRULD). It is widely known that RSI arise in subjects exposed to continuous and repetitive activities, who present complaints of pain, affecting mainly the upper limbs [8]. Among its many manife- stations, the Carpal Tunnel Syndrome results from the compression of the median nerve in the carpal tunnel causing reduction in nerve conduction to hand, affecting the worker's strength and sensitivity [41]. In this context, this study was aimed at analyzing the relationship between handgrip strength and hand tactile sensitivity, corresponding to the skin of the median nerve that controls the flexor muscles of forearm and hand.

Assessing sensitivity is very important for the prevention of peripheral neuropathy, since its diagnosis will contribute to prevent the advance of syndromes of peripheral nerves $[5,12]$. An instrument successfully used in the recovery of neurological injuries, especially diabetes and leprosy, is the

\footnotetext{
* Corresponding author: Pedro Ferreira Reis - Instituto de Ensino Superior de Foz do Iguaçu, Pr, Brazil - Universidade Federal de Santa Catarina - Programa de Pós Graduação em Engenharia de Produção - Ergonomia - Laboratório de Biomecânica - Campus Universitário, Trindade, Florianópolis, SC, Brazil. CEP: 88040970; Tel.(55)4837218530. E-mail: ergoreis@hotmail.com
} 
Semmes-Weinstein ${ }^{\circledR}$ monofilament, which was introduced in Brazil in the early 1980's [9,10,40, 47,50]. In Brazil, the Ministries of Health recognizes the importance of assessing the sensitivity as a tool for preventing injuries of the peripheral nerves, which is frequently reported in the handbook for the prevention of disabilities [11].

The sensory nerve stimulation in the extremities provides a nerve impulse to the Central Nervous System (CNS), which according to its specific area, codes, i.e., translates the impulse in its different forms of somesthesia [29]. These authors reported that the somatic region of the cerebral cortex is responsible for the transmission of sensory information through the peripheral nerves, which are provided by receptors located in the skin that through the afferent system, detect the sensory stimuli of cold, heat, sound, light, pain and touch [66].

The cerebral cortex is responsible for receiving sensitive information after stimulation, translating them and providing motor responses that can be both voluntary and involuntary [6,25], which is located at the outer region of the brain and is responsible for storing experiences, reception of sensory inputs and motor actions [13]. In this context, it is observed that the somatotopic structure indicates that the hand has a large area in the cerebral cortex; therefore, any nervous change in this representation will provide sensitivity changes in the individual [23].

The skin has receptors of deep, superficial and combined sensitivity, and the stimuli are captured by exteroceptors through the skin and subcutaneous tissue, responsible for the somesthesia of pain, temperature, touch and pressure [19].

The hand is the most important human organ to perform daily activities, with great mobility and stability to its articulation with wrist and fingers allows it a large number of functions, especially sensory and grip capacity, giving human beings the ability to perform complex to vigorous movements [30].

The skin has mechanoreceptors called Merkel's disk, free nerve ending, Meissner corpuscle, a hair follicle receptor, Pacinian and Ruffini corpuscles [8]. Each of these receptors has sensitivity capacity [19]. Thus, information obtained from the sensory signals of the skin is an important feature of the motor functionality [39].

The skin sensory receptors are distributed in the hairless and haired skin, and the Meissner corpuscle is responsible for touch, the Pacinian corpuscle for pressure, the Krause corpuscle for cold, the Ruffini corpuscle for heat and the free nerve endings for pain
$[8,37,52]$. In this sense, it is observed that the hairless skin has higher sensitivity, becoming an important site for the use of smooth skin in checking sensitivity and motor dysfunctions [35].

A major advantage in assessing the sensibility of peripheral nerves through the use of SemmesWeinstein esthesiometer is its easy application, low cost and the fact that the individual is blindfolded, making the achievement of false data impossible, which is a peculiar situation in the workplace where employees perform their duties with insecurity and fear of losing their jobs. In this context, SemmesWeinstein monofilaments ${ }^{\circledR}$ have wide use in assessing tactile and pressure sensitivity and in peripheral neuropathies of upper and lower limbs [11].

Consisting of a set of colorful monofilaments, Semmes-Weinstein monofilaments exert different pressures, which are detected according to their color, being green $(0.05 \mathrm{~g})$, blue $(0.2 \mathrm{~g})$, violet $(2.0 \mathrm{~g})$ and dark red $(4.0 \mathrm{~g})$, which range according to the loss of neural function (figure1).

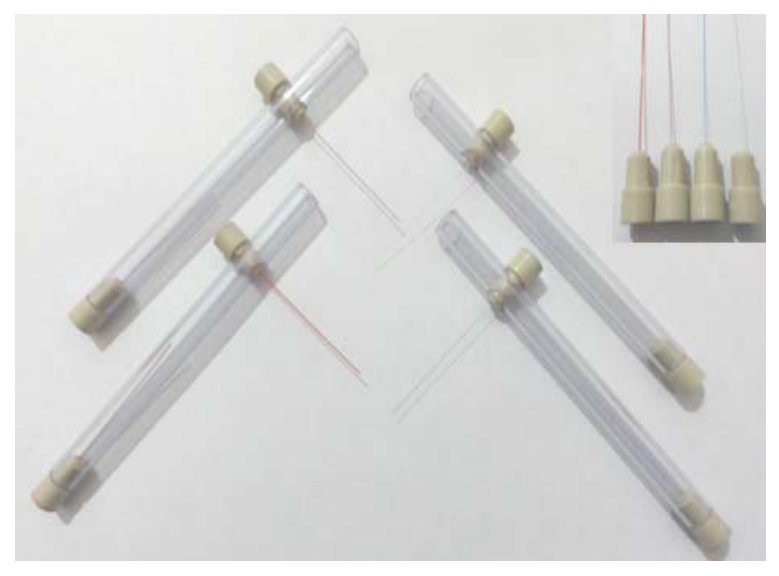

Fig. 1 - Semmes-Weinstein monofilaments used in esthesiometry. Source: $[9$, p.60]

Pressures indicate the severity of nerve damage, the greater the pressure on the innervated points, the greater the severity of the injury, being an instrument easy to apply [11].

The sensory receptors of heat, cold, pressure, touch and pain are found in the distal regions of the peripheral nerves, which are interpreted in the cerebral cortex for the later performance of the motor action $[11,20,31,42,48,66]$. The muscle functional capacity depends exclusively on the integrity of its neural pathway, because when the muscle has the nerve conduction under declining process, its atrophy 
begins, with decreased volume, loss of strength and sensitivity. Thus, measuring the strength in this case is of fundamental importance for early diagnosis [1].

The human hand is a multifunctional organ, being able to perform both power movements as delicate activities with sensitivity, which is essential for carrying out daily activities (DAs), but becomes useless if its neurological command stops working. When the conduction of the nerve that innervates the hand suffers an injury, all its functionality is impaired $[30,60,70]$. With innervation originating from the brachial plexus, in roots from $\mathrm{C} 5$ to $\mathrm{T} 1$, its motor functionality depends on the neural normality of the upper limb [14,30,33,46].

The brachial plexus is formed by the union of ventral rami of C5, C6, C7, C8 and T1, and in some cases, it can have the participation of $\mathrm{C} 4$ and $\mathrm{T} 2$. Roots C5 and C6 unite, they form the upper trunk, root $\mathrm{C} 7$ individually forms the middle trunk and roots C8 and T1 together form the lower trunk [58]. Continuing in the function of the brachial plexus, the upper, lower and middle trunks divide and form regions that innervate the anterior structures, responsible for the flexor action and posterior structures, responsible for the extensor action of the upper limb muscles [51]. Injuries of the peripheral nerves, which are more common in the upper limbs, provide serious consequences, because besides the loss of motor and sensory function, the functional disability will also lead to mental problems $[42,44,57]$. Thus, it is important to emphasize that individual factors such as gender and age will influence both in the emergence and in the recovery of the affected nerve [17].

The median nerve has its origin in the ventral rami of $\mathrm{C} 8$ and $\mathrm{T} 1$, innervating the muscles of the anterior forearm and short muscle of the thumb, being the main nerve responsible for the hand motor function, and when it is compressed at the carpal level, a pathology very common among workers occurs, affecting mainly women, called Carpal Tunnel Syndrome [69]. This author reports that the median nerve can be compressed during its pathway, leading to the appearance of the Pronator Teres syndrome, Anterior Interosseous Syndrome and Carpal Tunnel Syndrome, the latter being the most common among workers who perform repetitive tasks [31]. These authors report that the median nerve innervates the following muscles: palmaris longus, flexor carpi radialis, flexor digitorum superficialis of fingers, flexor digitorum profundus of index and middle fingers and square and round pronators (Figure 2). Therefore, when these muscles are affected, all the hand functionality will be compromised.

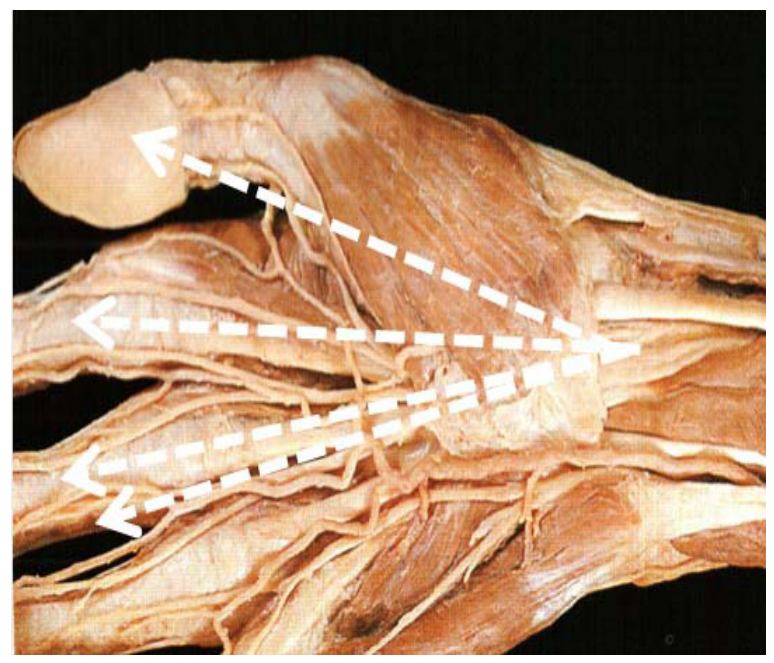

Fig. 02 - Innervation by the median nerve. Source: [34, p.320].

Several factors influence the health of workers, among them awkward postures, frequency of repetitive movement, use of force, lack of recovery pauses and anthropometric factors, which contribute to the emergence of compressive syndromes in the workplace, especially affecting women due to anthropometric and physiological differences [15]. Unfortunately, this situation persists today in work environments where men and women perform the same functions, highlighting the work organization of slaughterhouses, which impairs the development of prevention projects, contributing to the emergence of work diseases [56].

\section{Method}

\subsection{Participants}

This is a cross-sectional and observational research conducted with pig slaughterhouse workers in the city of São Miguel do Iguaçu, state of Paraná, Brazil. The sample was composed of 103 women aged 25 to 40 years, placed in jobs whose activities were repetitive by nature. Permission to participate in the study was obtained through the free and informed consent form (FICF). The procedures were approved by the local Committee for Ethics in Research with 
Human Subjects, according to the Declaration of Helsinki.

\subsection{Instruments}

Data were collected using two different tools: an esthesiometer composed of a Semmes-Weinstein Monofilament kit, whose purpose was to measure hand skin sensitivity in the region of the median nerve.

The protocol used for carrying out handgrip strength assessments was the same adopted and recommended by the Brazilian Society of Hand and Upper Limb Therapists (Figure3) [1].

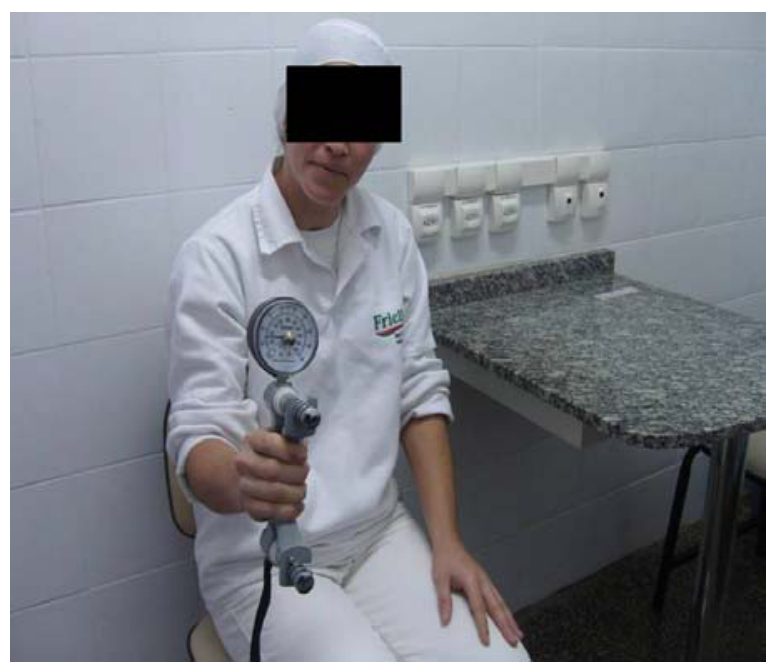

Fig. 3 - Handgrip strength. Source: [Athor]

The sensitivity measure corresponds to the thickness of the monofilament perceived by the subjects evaluated during the tests, and results could range among four categories according to the pressure on the skin in the chosen region, measured in grams (green $-0.05 \mathrm{~g}$, Blue - $0.2 \mathrm{~g}$, Violet $-2.0 \mathrm{~g}$ and Red $4.0 \mathrm{~g}$ ) from green, which represents normal sensitivity to red, which represents a total sensitivity deficit (Figure 4), and a Jamar ${ }^{\circledR}$ hand dynamometer, used to measure the handgrip strength in $\mathrm{kg} /$ strength (kgf) (Figure 3).

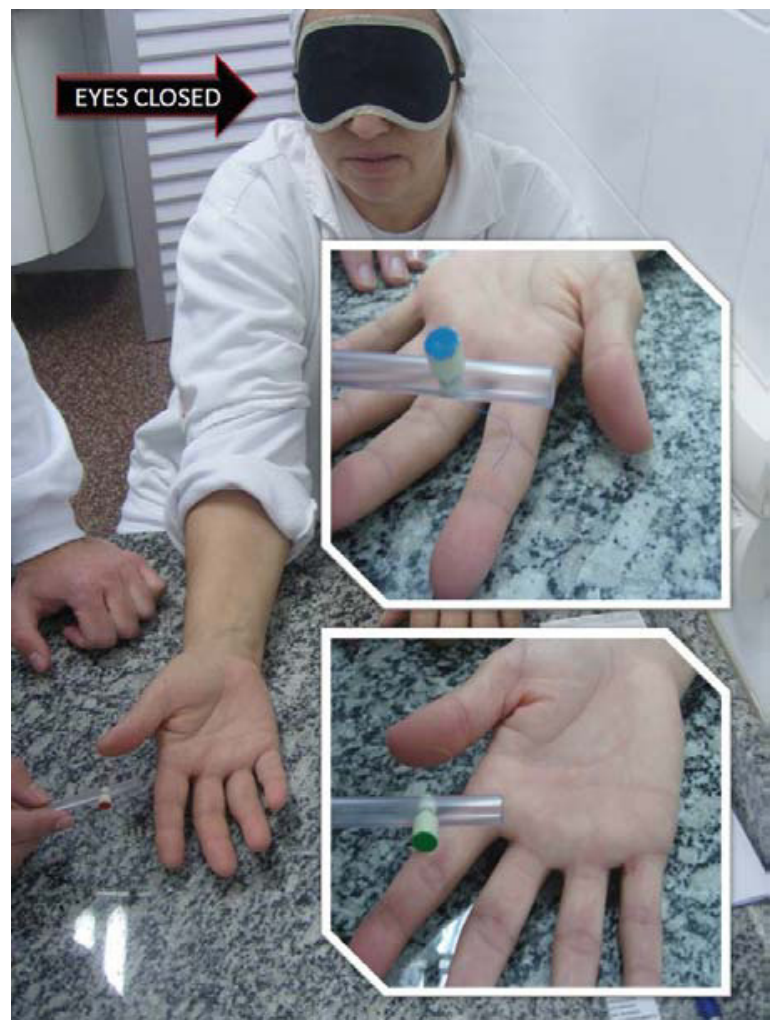

Fig. 4 - Sensibilidade do Nervo Mediano Fonte: Fonte: [Autor]

\subsection{Data Analysis}

Collected data were statistically analyzed by the Pearson correlation test, with the aid of the SPSS 14.0 software for Windows [7].

\section{Results}

According to Table 1 the esthesiometry results indicated that $81 \%$ of individuals assessed have normal sensitivity (green) and average handgrip strength levels in dominant hand (DH) of $35.30 \mathrm{kgf}( \pm 3.10)$ and in non-dominant hand (NDH) of $28.30 \pm 3.09$ kgf. For those who showed decreased sensitivity (14\%), values were equivalent to $0.2 \mathrm{~g}$ and $2.0 \mathrm{~g}$ (blue and violet) and handgrip strength levels in $\mathrm{DH}$ equal to $28.10 \mathrm{kgf}( \pm 2.90)$ and in NDH to $26.40 \mathrm{kgf}$ $( \pm 3.28)$. Another $5 \%$ of the individuals had bilateral severe sensitivity deficit $(4.0 \mathrm{~g})$ and handgrip strength levels in the DH of $\mathrm{kgf} 18.20( \pm 3.28)$ and in the NDH of $16.10 \mathrm{kgf}( \pm 210)$. The results indicated a strong correlation $(\mathrm{r}=0.786)$ between the variables related to the $\mathrm{DH}$ and in relation to the 
$\mathrm{NDH}$, slightly less significant $(\mathrm{r}=0.626)$. These results indicate a higher probability of carpal tunnel syndrome occurrence in the $\mathrm{DH}$, since the smaller the handgrip strength, the greater the association with hand sensitivity deficit.

Table1

Influence of Handgrip Strength in the nerve conduction of Medial Nerve

\begin{tabular}{|c|c|c|}
\hline kgf/Gender & $\begin{array}{l}\text { Handgrip } \\
\text { force }\end{array}$ & Sensitivity of the Medial Nerve \\
\hline $\mathrm{DH}$ & $\begin{array}{l}35.30 \pm 3.10 \\
\text { kgf. }\end{array}$ & $0.05 \mathrm{~g}$ - Normal Sensitivity \\
\hline $\mathrm{NDH}$ & $\begin{array}{l}28.30 \pm 3.09 \\
\text { kgf. }\end{array}$ & $0.05 \mathrm{~g}$ - Normal Sensitivity \\
\hline$\overline{\mathrm{DH}}$ & $\begin{array}{l}28.10 \pm 2.90 \\
\text { kgf. }\end{array}$ & $\begin{array}{c}0.2 \mathrm{~g} \text { and } 2.0 \mathrm{~g} \\
\text { Reduced Sensitivity }\end{array}$ \\
\hline $\mathrm{NDH}$ & $\begin{array}{l}26.40 \pm 3.28 \\
\text { kgf. }\end{array}$ & $\begin{array}{l}0.2 \mathrm{~g} \text { and } 2.0 \mathrm{~g}-\text { Reduced Sensi- } \\
\text { tivity }\end{array}$ \\
\hline$\overline{\mathrm{DH}}$ & $\begin{array}{l}18.20 \pm 3.28 \\
\text { kgf. }\end{array}$ & $4.0 \mathrm{~g}-$ Sensitivity deficit \\
\hline $\mathrm{NDH}$ & $\begin{array}{l}16.10 \pm 2.10 \\
\text { kgf. }\end{array}$ & 4.0g - Sensitivity deficit \\
\hline
\end{tabular}

\section{Discussion}

The isometric grip force of hand fingers is an important diagnostic of the upper limb functionality, and when damaged due to a weak innervation of the ulnar, median and radial nerves, represents an important indicator of RSI / WRULD [59]. Thus, it is important to emphasize that the human hand has high sensitivity level, being an organ of extreme importance to the social and economic life, its movements are manifested and controlled by the cerebral cortex and its innervation originates in the brachial plexus, in roots from $\mathrm{C} 5$ to $\mathrm{T} 1$. In this context, when this innervation is affected, especially in the chronic phase of RSI / WRULD, all the basic functions for daily activities (DA), leisure and work will be damage, sometimes progressing to a total loss of function of this limb $[8,16,20,21,48,53,64,72,73]$.

It has been observed that due to the search for productivity linked to inappropriate work environment and repetitive movements, disorders of the peripheral nerves, mainly in the upper limbs are frequent, and traumatic, compressive and degenerative complications are frequent within work organizations [68].

Resulting from the compression of the median nerve at the carpal tunnel level, the Carpal Tunnel Syndrome (CTS) provides motor and sensory disorders, affecting mainly strength and sensitivity $[65,70]$.

Any injury to the peripheral nerves of the upper limbs will be perceived by the hand receptors, since the neurological block, mainly of roots from C5 to T1, will impair the hand somesthesia, so that the use of the hand sensitivity is of fundamental importance to diagnose the affected nerve [34,61].

A nerve dysfunction should be detected early, which is a vital factor for an effective prevention of the injury, underscoring the hand sensitivity, since a compressive neuropathy of the upper limbs will provide loss of sensitivity, compromising the motor function [38].

The prominent growth of compressive syndromes of the nervous system concerns the occupational medicine, since the early diagnosis is still very difficult, mostly due to the lack of information provided to the employee or simply due to omission; they reach the chronic stage, leading to irreversible sequelae to sensitivity and motor functionality [18]. These authors report that all symptoms should serve as a warning, emphasizing formication, burning, and loss of sensitivity, since muscle atrophy and loss of strength indicate that the disease is in advanced stage, thus allowing for early intervention of nerve conduction disorders in order to prevent the reduced functionality of the affected nerve.

When the median nerve is affected, the entire handgrip strength will be impaired, since this nerve is responsible for the innervation of the thumb, index fingers and half of the ulnar nerve, being also responsible for the innervation of the opponens pollicis muscle, abductor pollicis brevis muscle, short flexor of the thumb and lumbrical muscle of middle and index fingers $[4,26]$. Neurological deficit should not be confused with fatigue arising from physical stress, since lactic acid and high levels of cortisol will contribute by the fall of motor units, to slower the muscle fiber velocity. These authors also reported that in both cases, the force is decreased [27].

Individuals affected by deficit of sensitivity have great difficulty in the performance of DAs, and falls, trips, dropping objects and breaking sensitive materials is a constant [22]. Thus, it is observed that the loss of sensitivity in the peripheral nerves of the upper limbs will contribute to the loss of strength, significantly affecting the autonomy of the affected individual $[22,32,36,55,63]$.

Based on these findings, it could be concluded that evaluating the nerve conduction of the median nerve by hand esthesiometry could be an important tool in the ergonomic analysis and periodic examina- 
tions of workers from these companies. Thus, this low-cost tool can be used in the prevention of the Carpal Tunnel Syndrome, preventing it from reaching the chronic stage of the injury.

\section{Acknowledgements}

This study was supported by the food company FRIELLA.

\section{References}

[1] L.M. Abdalla and M.C.F. Brandão, Força de preensão palmar e digital. In: Sociedade Brasileira de Terapeutas da Mão e do Membro Superior. Manual: recomendações para avaliação do membro superior. 2a ed. São Paulo: SBTM, 2005.

[2] ABEF, Associação Brasileira dos Produtores e Exportadores de Frangos (2010). Relatório anual 0910. Retrieved from: http://www.abef.com.br/portal/_clientes/abef/cat/RA_2010.pd f.

[3] M.J.J. Ares, Terapia Ocupacional na Reabilitação Física, São Paulo: Roca; 2003, pp.571.

[4] S. Aroori and R.A.J.Spence, Carpal tunnel syndrome, The Ulster medical journal, 77 (2008), 6-17.

[5] V.R.N. Barbosa, et al., Pain and numbness in the arms and hands and carpal tunnel syndrome diagnosis, Arq. Neuro Psiquiatr. 64 (2006), 997-1000.

[6] T.L. Barros, G. Angeli and L.F. Barros, Preparação do Atleta de Esportes Competitivos, Rev. Soc. Cardiol. Estado de São Paulo 15 (2005), 114-120.

[7] M.V.G. Barros and R.S.Reis, Análise de dados em atividade física e saúde: demonstrando a utilização do SPSS, $1^{\text {a }}$ ed. Londrina: Midiograf, 2003, pp.216.

[8] M.F.Bear, B.W.Connors and M.A. Paradiso, Neurociências Desvendando o Sistema Nervoso, 2a Ed., Porto Alegre: Ed. Artmed, 2002,pp.855.

[9] J. Bell Krotoski, Peripheral neuropathy and examination of the hands, The Star 50(1991), 15-17.

[10] J. Bell Krotoski and E. Tomancik, The repeatibility of testing with Lemmes Weins tein monofilaments, J. Hand Surgery 12 (1987), $155-161$.

[11]Brasil. Ministério da Saúde. Fundação Nacional de Saúde. Manual de prevenção de incapacidades. Brasília: Fundação Nacional de Saúde, 2008, pp. 60-62. Retrieved from: http://bvsms.saude.gov.br/bvs/publicacoes/manual_prevencao incapacidades.pdf.

[12] $\bar{C} . C$. Campos, et al., Paresthesia and/or pain affecting the hand and/or wrist as a referral for electrodiagnostic studies, Arq. Neuropsiquiatr. 61(2003), 56-60.

[13]M.A.Campos and B.C. Neto, Treinamento funcional resistido: para melhoria da capacidade funcional e reabilitação de lesões musculoesqueléticas, Rio de Janeiro: Revinter, 2004,pp.319.

[14] M.E.Chávez Delgado, et al., Secciones traumáticas de nervios periféricos en mano, Rev. méd. 39(2001), 295-302.

[15]D. Colombini, Método Ocra para a análise do risco por movimentos repetitivos: Manual para avaliação e a gestão de riscos. Editora LTR. São Paulo, 2008, pp.333.

[16]L.M. Conceição, Reabilitação da mão. São Paulo: Atheneu, 2005, pp. 231-253.

[17] L.B. Dahlin, The biology of nerve injury and repair, J. Am. Soc. Surg. Hand 4(2004), 143-155.
[18] J.L.B. da Silva, A. Gazzalle and C. Teixeira, Current approach to upper extremities entrapment neuropathies, Revista da AMRIGS, Porto Alegre 53(2009), 169-174.

[19]D. Doretto, Fisiopatologia Clínica do Sistema Nervoso: Fundamentos da Semiologia, $2^{a}$ ed. São Paulo, Atheneu, 2002, pp.496.

[20]L.L. dos Santos, et al., Carpal Tunnel Syndrome: reassessment of long-term outcomes with the use of the paine ${ }^{\circledR}$ retinaculatome during surgery through a palmar incision, Acta Ortop. Bras. 13(2005), 225-228.

[21]I.S.V.Ferrigno, P.P. Freitas and A.D.Freitas. Lesões dos nervos periféricos, In: Freitas PP, editor, Reabilitação da mão. São Paulo: Atheneu, 2005, pp. 211-230.

[22] J.R.Flanagan, M.C. Bowman and R.S. Johansson, Control strategies in object manipulation tasks, Current Opinion in Neurobiology 16(2006), 650-659.

[23]M.C.R. Fonseca, et al., Nervos periféricos: diagnóstico e tratamento clínico e cirúrgico, Rio de Janeiro: Revinter, 2003, pp. 233.

[24]E.D. Freitas, Manual prático de reeducação motora do membro superior na hemiplegia: fundamentado no método Brunnstrom. $1^{\mathrm{a}}$ ed. São Paulo: Memnon, 2000, pp.78.

[25] G.G.Freitas, O Esquema Corporal, A Imagem Corporal, A Consciência Corporal e a Corporeidade. Ijuí: Unijuí, 2004, pp.96.

[26]P.P. Freitas, Reabilitação da mão, Reimp. rev. Atual, São Paulo, Atheneu, 2006, pp.578.

[27]D.H.Gates, and J.B. Dingwell, The effects of neuromuscular fatigue on task performance during repetitive goaldirected movements. Exp Brain Res. 187(2008), 573-585.

[28] J.A.Gosling, P.F.Harris and J.R. Humpherson, Anatomia Humana, São Paulo: Editora Manole, 1992, pp.816.

[29]A.Guyton and J.L. Hall, Tratado de Fisiologia Médica de Guyton \& Hall. 11 ${ }^{a}$ edição, Rio de Janeiro: Guanabara e Koogan, 2006, pp.1264.

[30]J.E. Hamill and K.M. Knutzen, Bases biomecânicas do movimento humano, $2^{\mathrm{a}}$ ed. São Paulo: Manole, 2008, pp.494.

[31]D.G.V.Hardoim, G.B. Oliveira and J.A. Kouyoumdjian, Carpal tunnel syndrome: longterm nerve conduction studies in 261 hands. Arq. NeuroPsiquiatr. 67(2009), 69-73.

[32]J. Hermsdörfer, et. al., Preserved and impaired aspects of feedforward grip force control after chronic somatosensory deafferentation, Neurorehabil Neural Repair. 22(2008), 374384, 2008.

[33]S. Hopepenfeld, Propedêutica ortopédica: coluna e extremidades, São Paulo, Atheneu, 2005, pp.276.

[34]A. Jester, et al. Disabilities of the Arm, Shoulder and Hand (DASH) Questionnaire: Determining Functional Activity Profiles in Patients With Upper Extremity Disorders, J Hand Surg, St. Louis 30B(2005), 23-28.

[35]S.L. Juliano and D.F. Mclaughlin, Neurociência para fisioterapeutas: incluindo correlações clínicas, $2^{\mathrm{a}}$ ed. São Paulo, Manole, 2001, pp. 520.

[36] A.I. Kapandji, Fisiologia Articular. 6 ${ }^{\text {a }}$.ed. Rio de Janeiro, editora Guanabara Koogan, 2007, pp.280.

[37] J.A Kiernan, Neuroanatomia humana de Barr. $7^{\text {a }}$ ed. Rio de Janeiro, editora Manole, 2003, pp.518.

[38]F.F. Koelewijn, et al., Sensory testing in leprosy: comparison of ballpoint pen and monofilaments Leprosy Review 74(2003), 42-52.

[39]K. Kohlmeyer, Sensory and Neuromuscular Function. In: Crepeau BE, Cohn ES, Schall AB. Willard \& Spackman's Occupational Therapy, Philadelphia: Lippincott Williams \& Wilkins; 2003, pp. 365-69. 
[40]L.F.Lehman, et al., The development and adaptation of the SemmesWeinstein monofilaments in Brazil, J. Hand Ther. 4(1993), 290-297.

[41] S.M.P.F.Lima, et al., Evaluation of tactile sensitivity in adults with superficial damage to the central system: implications in assisting occupational therapy, O mundo da saúde 30(2006), 73-80.

[42] G. Lundborg, Nerve injury and repair: regeneration, reconstruction and cortical remodeling, $2^{\mathrm{a}}$ ed. New York: Churchill Livingstone, Chap, Sensation and sensorimotor integration in hand function, 2005, pp.198-244.

[43] G. Lundborg and B. Rosén, A model instrument for the documentation of outcome after nerve repair, J. Hand Surg. 25(2000), 435-438.

[44] G. Lundborg and B. Rosén, The longterm recovery curve in adults after median or ulnar nerve repair: a reference interval, J Hand Surg. 26B(2001), 196-200.

[45]L. Lundyekman, Neurociência. Fundamentos para a Reabilitação, $1^{\mathrm{a}}$ Ed., Rio de Janeiro: Ed. Guanabara Koogan, 2000. pp. 471-477.

[46]D.J. Magee, Avaliação Musculoesquelética, $4^{\mathrm{a}}$ edição Barueri: Manole, 2005, pp.1014

[47] L.H.S.C. Marciano and J.A. Garbino, Comparison of monitoring techniques of leprosy neuropathy: sensibility test and study of neural conduction, Hansen, Int. 19(1994), 5-10.

[48]A.M. Marcolino, et al., Physical therapy rehabilitation of the brachial plexus injury: case report, Fisioter. Mov. 21(2008), 53-60.

[49]L. Mercier, et al. Impact of Motor, Cognitive and Perceptual Disorders on Ability to Perform Activities of Daily Living After Stroke, Stroke 32(2001), 2602-2608.

[50]D. Moreira, et al., Use of Semmes -Weisntein monofilaments to evaluate sensitivity of upper limbs of Hansen's diseasep atients attended in the Federal District Hansen.Int. 24(1999), 121-128.

[51]E. Narahashi, et al., Image Diagnosis of Brachial Plexus, Rev. Bras. Reumatol. 45(2005), 245-249.

[52]F.H.Netter, Atlas de Anatomia Humana, $4^{\mathrm{a} e d .}$ Porto Alegre: Artmed, 2008, pp.593.

[53]C.B. Novak and S.E. Mackinnon, Evaluation of nerve injury and nerve compression in the upper quadrant, Journal Hand Therapy 18(2005), 230-240.

[54]D.A. Nowak and J. Hermsdörfer, Objective evaluation of manual performance deficits in neurological movement disorders, Brain research reviews 51(2006), 108-124.

[55]D.A. Nowak and J. Hermsdörfer, Selective deficits of grip force control during object manipulation in patients with reduced sensibility of the grasping digits, Neuroscience Research 47(2003), 65-72.

[56] J.R.G. Oliveira, A prática da ginástica laboral, $3^{\mathrm{a}}$ ed. Rio de Janeiro, editora Sprint, 2006, pp.136.

[57]A. Ranzzi, A. Severo and M. Costa, Membro superior: a abordagem fisioterapêutica das patologias ortopédicas mais comuns. Rio de Janeiro: Revinter; 2005, pp. 38-52.

[58] D.L. Reede and R.A. Holliday, Brachial Plexus, Head and Neck Imaging, $4^{\mathrm{a}}$ ed, Mosby 2(2003),2216-2218.

[59]F.C.B. Rodini, et al., Disability prevention in leprosy using a self-care manual for patients, Fisioterapia e Pesquisa 17(2010),157-166.

[60]H.E. Rosberg, et al., Injury to the human median and ulnar nerves in the forearm -analysis of costs for treatment and rehabilitation of 69 patients in Southern Sweden, J. Hand Surg. 30(2005), 35-39. 2005.

[61]A.C.Ruijs, et al. Median and Ulnar Nerve Injuries: A MetaAnalysis of Predictors of Motor and Sensory Recovery after
Modern Microsurgical Nerve Repair, Plast Reconstr Surg, Baltimore 116(2005), 484-494.

[62] S.W.Shaffer and A.L. Harrison, Aging of the Somatosensory System: A Translational Perspective, Physical Therapy 87(2007), 193-207.

[63] M. Schenker,et al. Precision grip function after hand replantation and digital nerve injury, Journal of Plastic, Reconstructive \& Aesthetic Surgery 59(2006), 706-716.

[64]A.E. Shumway-Cook and M.Woollacott, Controle motor. Teoria e aplicações práticas. $2^{\mathrm{a}}$ Ed., São Paulo, editora Manole, 2003, pp. 513-517.

[65]T.L. Skare, et al. Considerations about Carpal tunnel syndrome with emphasis on treatment, Revista de Reumatologia 87(2004), 34-37.

[66]R.S.Snell, Neuroanatomia Clínica para Estudantes de Medicina, 5 ${ }^{\text {a }}$ Ed., Rio de Janeiro: Ed. Guanabara Koogan, 2003, pp. 83-119.

[67]R.W. Staines, et al., Somatosensory Gating and Recovery from Stroke Involving the Thalamus, Stroke 33(2002), 26422653.

[68] M.Tatagiba, et al., Nervos periféricos Diagnóstico e tratamento clínico e cirúrgico, Rio de Janeiro: Revinter, 2003, pp.233.

[69] M.D.M. Teixeira, et. al., Grip and pinch strength in Brazilian Air Force cadet pilots: a comparative study between men and women, Fisioterapia e Pesquisa, São Paulo 16(2009), 43-71.

[70]E. Turrini, et al., Image Diagnosis of Carpal Tunnel Syndrome. Rev Bras Reumatol. 45(2005), 51-53.

[71]L.A.Venstevens, et al. Clinimetric properties of instruments to assess activities in patients with hand injury: a systematic review of the literature, Arch. Phys. Med. Rehabil. 90(2009), 151-169.

[72]M.T. Walsh, Upper limb neural tension testing and mobilization: fact, fiction and a practical approach. Journal of Hand Therapy 18(2005), 241-258.

[73] W.J. Weiner and C. G. Goetz, Neurologia para o Não Especialista. Fundamentos Básicos da Neurologia Contemporânea, 4 ${ }^{a}$ Ed., São Paulo: Ed. Santos, 2003, pp. 187193. 